Mirjana Rašević

Institute of Social Sciences

Belgrade
UDK: 314.186.

Original Scientific Paper Received: 12. 8. 2008.

\title{
SERBIA: TRANSITION FROM ABORTION TO CONTRACEPTION OR NOT?
}

At the end of demographic transition and in its post-transitional phase, according to Tietze's model, contraception has become a dominant method of birth control, while induced abortions lag behind with insignificant participation. The stated model is of general type and refers to developed countries today. It is possible that there are some differrences among them, but to a small extent. However, significant and even great differences exist between Tietze's model and the relation between contraception and induced abortion in Serbia. This paper deals with the phenomenon of the domination of traditional birth control in Serbia and seeks a reply to the question whether the beginning of the $21^{\text {st }}$ century marks a shift in this sphere.

Kew words: induced abortion, contraception, Serbia.

Parallel with the fertility transition, development of contraception and liberalization of abortion, a certain relationship appeared among these three phenomena. Bearing in mind the different levels of each of them in the course of demographic development, Christopher Tietze (1974) differentiates three stages of this relation. Prior to demographic transition, the level of births was high and birth control was insignificant, whereas induced abortion was far more widespread than contraception. In the first phase of demographic transition, fertility slowly decreased, the number of abortions rapidly increased, while contraception only insignificantly increased. In the second phase of transition, fertility continued to decrease; abortion increased for another short period and then started to decrease under the influence of a greater use of contraception. In the third phase, fertility stabilized at a low level, abortions continued to decrease, and contraception increased.

At the end of demographic transition and in its post-transitional phase, according to Tietze's model, contraception has become a dominant method of birth control, while induced abortions lag behind with insignificant participation. The stated model is of general type and refers to developed countries today. It is possible that there are some differences among them, but only to a small extent. However, significant and even great differences exist between Tietze's model and the relation between contraception and induced abortion in Serbia. Namely, at the same time, our society is characterized with a low level of fertility and traditional models of birth control. 


\section{Domination of the traditional model of birth control}

The reproductive health problem of Serbia's population lasting several decades lies in the widespread conservative birth control method in which reliance on coitus interruptus prevails. A large number of researches proved that coitus interruptus is the contraceptive method with which many women begin protection in their reproductive age and which is used the most in this period. Psychological pressure and the psychological price of this contraception method are not great. It is conceived as a method which is not harmful to health. There is no need to previously contact a physician for its use. A fundamental conflict between sexuality and technology is avoided. Reliance on coitus interruptus does not provoke partner conflicts but supports the active sexual role of the man. The choice of inefficient contraception suits passive persons, whose psychological functioning is characterized by anticipation, submission, returning to same situations and circle of events as well as making mistakes.

Traditional inefficient contraception, largely incorporated in the system of values, has become a natural part of sexual relations in our country and represents a rational preventive choice from the individual standpoint. Consequentially, when pregnancy is unwanted or cannot be accepted, abortion is used as a resort. Thus the long history of a large number of abortions in Serbia.

The problem of a large number of abortions in our country was first pointed out at the 17th Congress of Yugoslav Physicians (Belgrade, 1935). The Head Health Care Council estimated the total number of abortions (legal and illegal) at about 300,000 a year (Novak, 1964). Although there are no estimates of the number of abortions performed in that period of time in Serbia, it could be assumed that abortion was practiced on a large scale.

The data on the number of induced abortions performed in Serbia in 1960 $(81,516), 1961(95,196)$ and $1967(131,502)$ are incomplete, but even so, they are indicative of a large number of abortions performed in medical institutions. It was the result of the expansion of the network of medical institutions qualified for abortions and the gradual liberalization of the right to perform abortions. This was corroborated by a survey conducted by the Federal Public Health Bureau in 1964, the results of which showed that more than 95 percent of the total number of legal abortions were performed on social grounds, and only 5 percent on medical, legal and ethic ones (Mojić, 1967).

Reliable data on induced abortions in Serbia exist from 1969, the year of complete liberalization of abortions, up to 1989 and they substantiate the existence of endemic abortions in that time period. Namely, from 1969 to 1985 the number of induced abortions continuously increased. It grew from 162,643 in 1969 to 214,806 in 1985 or by one third (index 132). It should be underlined that in this period the number of induced abortions increased considerably faster up to 1980 . The data for the years 1986, 1987 and 1988 indicate a gradual decrease of the 
absolute number of abortions in Serbia (212,400; 205,343 and 193,558 respectively). At the level of 193,755 in 1989 , the total number of induced abortions was minimally higher than in the previous calendar year.

Relatively expressed, induced abortions showed the same trends. A relative increase in the number of induced abortions had been noted up to 1985 or 1986, when the number of abortions measured to live births and the number of women in their fertile period began to decrease. The number of abortions estimated on 100 live-born children in 1969 amounted to 107.0, in 1986 - 138.0, and in 1989 133.7. The abortion rates indicate that every fourteenth woman in her reproductive age had an abortion in 1969, every eleventh in 1985 and every twelfth in 1989.

The structure of women which underwent induced abortions in 1989 in Serbia showed that $90 \%$ of them were between 20 and 39 years of age, more than $90 \%$ were married, $75.8 \%$ had one or two children, and almost every fourth woman (22.4\%) had 4 or more induced abortions in their reproductive history.

Observed on a regional level, the crucial influence on the abortion problem in Serbia come from the low-natality regions. In terms of the number of abortions to 1000 women aged 15-49 years, induced abortions were the most widespread in Central Serbia in 1989 (95.1 of every 1000 women in their fertile period), then in Vojvodina (74.1) but far less in Kosovo and Metohia (24.1). The low level of abortions in Kosovo and Metohia is primarily explained by the high level of births in this region.

Since the nineties of the last century there have been great problems regarding the gathering of data on induced abortions, although registration of every fetal death is a legal obligation. Distrust in the reliability of data regarding registration of induced abortions appeared in 1990. It was based on a completely different tendency of abortions in regions with the same reproductive model. Namely, Central Serbia registered a mild decrease, while Vojvodina a high increase (24.8\%) of the number of abortions. In the following years, the number of registered abortions was considerably underestimated. Thus in 1999, 43,771 abortions were registered in relation to 193,755 recorded in 1989 . The radical change was not realistic having in mind the endurance of this phenomenon as well as the new living conditions, above all the economic and psychological existential instability, various problems regarding the availability of contraception and existence of numerous private gynecological clinics. It can even be assumed that during the nineties there had been an inversion of the determined trend of mild decrease of abortions at the end of the last decade.

Does the beginning of the $21^{\text {st }}$ century mark a shift in this sphere? In order to get an answer to this question, we will compare the available data regarding the use of contraception. The results of a representative research on the health state of Serbia's population (not including Kosovo and Metohia) conducted in 2006 indicate that $18.6 \%$ of women uses modern contraception, namely the condom, combined oral contraception or intrauterine device (Ministry of Health, 2007). The determined percentage is low and even considerably lower than the relevant 
Mirjana Rašević, Serbia. Transition from Abortion to Contraception or Not?

percentage determined by the same methodology in the year 2000 when $33.0 \%$ of married women, or those in a partner relation, aged between 15 and 49 registered that they were using modern contraception (UNICEF, 2000).

Has there been any change in the usage of modern and efficient contraception among young couples? The results of the stated representative research on the health state of Serbia's population show that the largest number of women which are at risk for pregnancy relies on traditional contraception methods both at the beginning and the end of their reproductive period. Namely, modern contraception methods are used by every tenth woman (11.6\%) aged between 20 and 24, in comparison with every eighth woman $(13.1 \%)$ in the age group between 45 and 49 years old (Ministry of Health, 2007).

\section{Deterministic basis for relying on traditional contraception and induced abortion}

More than a century ago, Freud wrote the following, contemplating on the theme of birth control: "It cannot be denied that contraceptive measures are becoming necessary in marriage and, theoretically speaking, it would be one of the greatest successes of mankind if the act of procreation could be raised to a level of a willing and intentional act and liberated from the connection with the necessary satisfaction of natural desire". By contemporary methods of contraception it is possible to separate sex from procreation and biological reproduction can become a willing and intentional act of people which Freud wrote about. However, the stated findings indicate to a contradictory situation and open many questions, the most important being why there is no transition from the use of traditional contraception and induced abortion towards modern and efficient contraception methods and means in Serbia. Despite theoretical discussions and numerous researches, the answers to this question are neither complete nor final.

Some answers are imposed. According to May (1969) distinguishing sex from reproduction "may increase ambivalence in people. There also exists a dilemma of personal responsibility for the freedom of choice... we never accepted the psychological and personal responsibility for that ... because God does not decide anymore whether or not we will have children, we do. However much we wanted this new freedom, it opens the doors to new dilemmas and contemporary anxieties."

Research breakthroughs in our country (Rašević, 1993; Ristić, 1994; KaporStanulović, Kapamadžija, 2000, Rašević, Sedlecki, 2007) though, have distinguished specific factors regarding the non-acceptance of modern values in this sphere. Among them, the most important are that traditional contraception and abortions have a firm social confirmation, that sexual education had never become a natural way of growing up in the family nor a constituent part of school programs, that great psychological resistance towards the use of combined oral contraception and 
Социолошки преглед, vol. XLII (2008), no. 3, стр. 295-305

intrauterine devices exists, and that by relying on coitus interruptus conflict is avoided between sexuality and technology, contact with physician as well as conflict with the partner.

Traditional contraception and induced abortions have a firm social confirmation in Serbia. Generations of women and men prevent conception by resorting to coitus interruptus and, in case of failure of this method, to abortion. At the same time, an organized and systematic social influence in this sphere has been left out. Liberalization of abortion came, according to the model from the Soviet Union, at the time of a decrease of fertility and quite modest presence of certain modern contraceptive means. Introduction of combined oral contraception and intrauterine devices is harder in conditions when liberated access to abortion already exists for a long time. Inertia is also an important behavioral factor in birth control, especially in conditions when legal regulation of induced abortions was not accompanied by the carrying out of a family planning program which would promote different values regarding reproductive behavior and introducing sexual education.

Sexual education never became neither a natural way of growing up in a family nor a constituent part of school programs, namely health prevention actions. Themes regarding sexual life and birth control are superficially mentioned in newspapers and they are more or less partially or sporadically discussed in a circle of friends. This is the main reason for the insufficient knowledge on the physiology of procreation, on the risks of induced abortions and on contraception. The results of surveyed research clearly showed that most women do not know anything on these themes. Elementary knowledge is lacking as well as knowledge on phenomenon that women constantly encounter. Traditional beliefs and standpoints only bring confusion. It is important to point out to the great restrictiveness of women. The first negative experience, one's own or somebody else's, with some form of contraception is generalized and included as an important dimension of knowledge. Once something is learned, spontaneously, without understanding, it is not verified. Uniformity of wrong answers is imposed. The reservation of a number of women towards new knowledge is incomprehensible. Education is a factor which determines the differences in the level of knowledge, but not to such an extent that it should.

Psychological resistance towards the use of combined oral contraception and intrauterine devices is great and is even passed on between generations. Efficient contraception for most women is not a logical solution to the dilemma on birth control. They perceive traditional contraception, which includes abortion, as an equivalent solution which, on the whole, psychologically burdens them even less. The most significant component which influences the formation of the psychological price of modern contraception is that it is harmful to health. Other important components include: experiencing modern contraception as obliging, unnatural, irritating and thus unpleasant, complicated usage and it is a source of conflict with the partner. Most of the reasons women stress as being important for 
Mirjana Rašević, Serbia. Transition from Abortion to Contraception or Not?

giving up condoms, combined hormone contraception and intrauterine devices are subjective and of psychological nature. The list of reasons include those that could be a placebo reaction as well as those which present a mask to the ambivalence regarding sexual identity, sexual potential, sexual desires and requests, namely undefined feelings on their own reproduction. Withdrawal from contraception is often the easiest way to avoid solving sexual conflicts with the partner.

Psychological resistance to modern and efficient contraception is not only characteristic for women. Numerous unwanted pregnancies happen because men avoid taking part in bringing a decision on the birth control method leaving it to the woman alone, which mostly means that she will bear the consequences of such a decision by herself. In addition, many men support only female contraception means which provokes thought on the role of the psychological price in such a decision. A considerable number of men are strongly against the use of contraception. Explanations are mainly a rationalization of psychological resistance. They insist on the harmfulness of modern contraception on the health of their partner, namely on contraception as the cause of illness. It is not understood that orientation toward prevention of conception by means of efficient contraception is one of the important prerequisites for a healthy way of life.

Gynecologists themselves, generally speaking, contribute to maintaining the abortion culture and to the slow transition of birth control by means of traditional contraception towards reliance on modern means and methods in conception prevention. A considerable number of gynecologists in our country come into conflict with the principles of the modern concept of family planning. Their knowledge, standpoints and practice relevant for individual contraceptive choices are insufficient, conservative and inadequate. Thus coitus interruptus is the most popular method in conception prevention among gynecologists as well, and almost two thirds of gynecologists and their partners underwent induced abortion. Every fourth gynecologist had experience, directly or indirectly, with two abortions, every tenth - with three abortions, and with four or more induced abortions - every thirteenth gynecologist.

Distinct obstacles of various nature exist with regard to the availability of modern contraception in Serbia. The most important are: high cost, nonexistence of a legal basis for using voluntary sterilization as a reserve for decreasing the numbers of multiple abortions and barriers concerning contraception counseling services.

For example, the standpoints of women on a successful contact with counseling services show how much they are disoriented and left to themselves and in what need they are for professional relations and help. Women are not only aware of the conflict "she-contraception counseling services", but they intuitively bring out numerous suggestions as solutions within the program for family planning of developed countries. 


\section{Consequences of endemic abortion}

Abortion is a realistic necessity conditioned by numerous factors of various nature. The distinguished factors include: historical roots, moral principals of our civilization, human rights concept, limitations of births especially intensive control of biological potential, abortion characteristics as a method of birth control, objective limitations of contraception and their subjective experience, as well as characteristics of women and men, primarily of psychological and social nature. However, dominant reliance on conservative and inefficient contraception which includes abortion is not a logical solution to the dilemma on birth control method not only because it is the least acceptable form but, above all, because of its serious consequences on both the individual and society.

On the micro level, there are health, psychological and social consequences of abortion, and on the macro level, induced abortion has an effect on fertility level and population reproductive potential. The analysis of complications of induced abortion in Serbia relies on partial investigations by a number of gynecologists and several studies treating this problem in a more complex manner. Unfortunately, no representative study on this issue has ever been made nor do post abortion complications make up a part of the national program on health statistics.

The biggest study, a study made by the Gynecology Obstetrics Clinic from Belgrade on 2359 women in Serbia, shows that early complications of induced abortion occur in $21.3 \%$ of cases and display large variations. Every tenth abortion in Vojvodina, every fifth in Belgrade, i.e. almost every third in Central Serbia (excluding Belgrade) implies complications (Malačić, 1983). The incidence of early complications can be assessed as high. Such frequency of complications following induced abortion is characteristic for less developed countries. It is, however, difficult to compare our data with those of the industrialized world because of the differences in the manner of data compilation and definition of individual complications. The percentage of complications is certainly inflated by the fact that every complication which is subjectively felt by a woman and not objectively checked is also included.

But, results of a series of investigations confirmed that severe early complications of abortion are rare, though the risk of their occurrence is higher compared to the industrialized countries. Thus, for example, perforation of the uterus occurs in 665 abortions (Antonovski, 1980). Early complications of abortions are often the cause of chronic complications. In the stated study, through testing 21 socio-economic, demographic and medical variables, it was determined that induced abortions, and especially the number of induced abortions in the reproductive history of women, were statistically significant factors of secondary sterility, spontaneous abortions and premature births (Milačić, 1983)

Psychological consequences of induced abortions were also researched. Results of the representative survey questionnaire on the causes for a large number 
Mirjana Rašević, Serbia. Transition from Abortion to Contraception or Not?

of abortions in Belgrade have confirmed that abortion is a difficult experience for many women (Rašević, 1993). About $45 \%$ of women show unexplained emotional reactions towards abortion even two months after the intervention. The psychological trauma varies in degree. In retrospect, abortion is felt as a difficult experience but without cognitive signs (14.0\%), a painful experience which often comes to mind $(14.6 \%)$ or, an experience which is so disturbing that one prefers not to think about it (15.9\%). Induced abortion causes unresolved psychological reactions twice as often for women who experienced abortion for the first time. To them, abortion is more often both a painful and disturbing experience they would rather not think of. It is, however, important to underline that more than one third of the women interviewed who have had two or more induced abortions in their reproductive history, have some kind of psychological reaction to their latest termination of pregnancy.

\section{Promotion of modern and efficient contraception}

The problem of the domination of conservative birth control in Serbia and the consequences of endemic abortion are serious and demand numerous program actions. The principal solutions are to propagate relevant knowledge, develop a network of services for contraception organized to respect the principles of efficiency in work, including specially educated doctors and various health workers in counseling for promotion of preventive behavior, complete availability of efficient contraception, getting men out of the defensive and development of their responsibility in this sphere, legal regulations of voluntary sterilization as an instrument for decreasing the number of induced abortions, especially multiple abortions.

Special, target groups for propagating relevant knowledge are the adolescents, less educated women, housewives and blue-collar female workers, women who grew up in small towns, women with a low score on personal efficiency scale and especially women who have had abortions, namely women who had abortions as adolescents.

Research in many places have shown that women are motivated and ready to change their method of birth control immediately after induced abortion. Consciousness on the need to change behavior is weak to really change behavior in the near future. Thus a discussion with the doctor is of utmost importance on all relevant matters in the post-abortion phase in order to influence formation of a standpoint, as well as creating motivation, stimulating responsibility, forming a different system of values and life philosophy in the sphere of reproductive health, before the woman gets passive, returns to the same circle of occurrence and makes the same mistake.

On the contrary, in the absence of a systematic and long-term carrying out of program actions for the purpose of accepting modern and efficient contraception, the domination of conservative birth control and endemic abortion will continue in 
Социолошки преглед, vol. XLII (2008), no. 3, стр. 295-305

Serbia. Namely, we will still have reflections of women on the condom, combined oral contraception and intrauterine devices similar to those received in a survey on the causes of a large number of abortions in Belgrade (Rašević, 1993). Some are cited:

"I am disgusted by the preservative", (biology student, 21, one abortion).

"I am horrified by the mere thought of the preservative", (clerk, 27, three abortions).

"I call sex with a condom - sex with gloves", (saleswoman, 29, four abortions).

"A condom hurts and stings", (administrator, 39, four abortions).

"A condom is such a nuisance", (film operator, 30, six abortions).

"You interrupt sex to put on the condom. Where is the spontaneity?" (anesthesiologist, 36, three abortions).

"I used the pill only seven days. I was vomiting constantly. My eyes blurred. I felt so bad I had to call an ambulance. The doctor yelled at me", (legal adviser, 31, four abortions).

"I took the pill for only one day. I had a splitting headache. I thought I was going to die", (saleswoman, 37, six abortions).

"The intrauterine device changes the position of the uterus", (sales consultant, 32 , five abortions).

"The whole uterus swells from the intrauterine device just like when you have a splinter in your hand and then it turns red and swells", (economist, 30, five abortions).

"The intrauterine device creates a tumor in the uterus and that is how it prevents pregnancy", (textile worker, 36, five abortions).

The noted reflections of women on efficient contraception illustrate ignorance, great psychological resistance and irrationalism in behavior regarding birth control. At the same time, it underlines the necessity of promoting modern and efficient contraception through all known channels and point out to the difficulties which will be encountered in the realization of future actions in this sphere.

The long-lasting problem of the widespread acceptance of the traditional model of birth control points out to numerous and stable factors which cause it. Taking this fact into consideration, as well as the idleness of spontaneous changes, it is expected that reliance on traditional contraception, which includes induced abortion as a consequence, will be present in the years to come as well.

On a wider scale various alternatives are possible. The first alternative assumes a radical increase in the number of abortions as a consequence of full commercial use of the abortion pill RU-486. The second variant is based on the realization of the idea regarding the vaccine against conception and consequential radical decrease of the number of induced abortions. The variant with the best chances is the one that assumes a mild decrease of abortions under the influence of greater use 
Mirjana Rašević, Serbia. Transition from Abortion to Contraception or Not?

of modern and efficient contraception. This process could be more or less spontaneous which would mean that transition from traditional to modern contraception would last a long time. The possibility remains though, that the state will pay considerably more attention to this question than up to now. The capability and readiness of the state to solve a serious problem of the widespread use of traditional model of birth control will determine the length of its duration.

It should be stressed that the choice for restrictive legal solutions regarding induced abortions is not only contrary to the moral principles of our civilization, that it has a high health and psychological price, but that it is not even efficient enough in liberal surroundings. Abortion is a realistic necessity, the only completely efficient method of conception prevention and the only form of birth control based on certainty, but not probability of conception. However, apart from that, a large number of abortions in a population at the beginning of the $21^{\text {st }}$ century is unacceptable.

\section{Literature}

Antonovski, A. (1980) "Medical Aspect of Induced Abortion", Fertility and Family Planning in Yugoslavia, Demographic Research Centre, Institute of Social Sciences, Belgrade.

Bulatao, R., Bos, E. (1992) "The Spread of Fertility Regulation as Collective Behaviour", Family Planning Programmes and Fertility, Clarendon Press, Oxford.

Freud, S. (1959). Sexuality in the Etiology of the Neuroses (New York: Northon).

Hatcher, R.A., Rinehart W., Blackburn, R., Geller, J., Shelton J. (2005) The Essentials of Contraceptive Technology Johns Hopkins Bloomberg School of Public Health, Population Information Program, Baltimore.

Gerson, K. (1985) Hard Choices, University of California Press, Berceley, Los Angeles, London.

Капор-Стануловић, Н., Капамаџија, А. (2000) "Follow-up студија о знању и понашању младих у регулацији фертилитета (1964-1980-2000)", Социјална мисао, број 3-4.

May, R. (1969) Love and Will, Northon, New York.

Милачић, Д. (1983) Медицински и социјални аспекти проблема хумане репродукиије у СР Србији, докторска дисертација , Медицински факултет, Београд.

Министарство здравља (2007) Истраживање здравља становника Републике Србије (Београд: Министарство здравља).

Мојић, А. (1967) Побачај и регулисање зачећа, Медицинска књига, Београд.

Новак, Ф. и сарадници (1964). "Проблем нежељене трудноће", Зборник радова - V конгрес гинеколога опстетичара Југославије (Сарајево).

Pearce, K. J. (1981) "Psychological Factors and Unwanted Pregnancy", Abortion: Readings and Research, Butterworths, Toronto.

Рашевић, М. (1993) Ка разумевању абортуса у Србији, Центар за демографска истраживања Института друштвених наука, Београд.

Рашевић, М. (1999) Планирање породице као стил живота, Центар за демографска истраживања Института друштвених наука, Београд. 
Сочиолошки преглед, vol. XLII (2008), no. 3, стр. 295-305

Рашевић, М., Седлецки, К. (2007) "Гинеколози и абортус", Становништво, број 1.

Ристић, Ј. (1994) "Здравствени радници и планирање породице", Становништво, број 3-4.

Rodman, H. (1987) The Abortion Question, Columbia University Press, New York.

Segal, S., Tsui, A., Rogers, S. (ed.) (1989) Demographic and Programmatic Consequences of Contraceptive Innovations, Plenum Press, New York.

Tietze, C. (1974) "Overview", Abortion, Fertility and Changing Legislation: An International Review, Lexington Books, Lexington.

UNICEF (2000) Multiple Indicator Cluster Survey II, The Report for The Federal Republic of Yugoslavia, UNICEF, Belgrade.

Мирјана Рашевић

Резиме

Институт друштвених наука

Београд

\section{СРБИЈА: ТРАНЗИЦИЈА ОД АБОРТУСА КА КОНТРАЦЕПЦИЈИ ИЛИ НЕ?}

Вишедеценијски проблем репродуктивног здравља становништва Србије је распрострањеност конзервативне контроле рађања у којој доминира ослањање на coitus interruptus. Традиционална контрацептивна средства и методе, у великој мери инкорпорирана у систем вредности, постала су природни део сексуалног односа и представљају, с индивидуалног становишта, рационалан превентивни избор. Но последично, када се из различитих разлога трудноћа не жели или не може прихватити, прибегава се намерном прекиду трудноће. Отуда дуга историја великог броја абортуса у нашој средини. Ослањање на конзервативну и неефикасну контрацепцију која укључује абортус није логично решење дилеме о виду контроле рађања не само што је намерни прекид трудноће цивилизацијски и морално најмање прихватљив метод већ, пре свега, због последица које се тичу и индивидуе и друштва. На микро нивоу последице су здравствене, психолошке и социјалне, а на макро нивоу абортус утиче на смањење плодности и репродуктивног потенцијала становништва.

Да ли почетак 21. века обележева помак у овај сфери? Да ли постоје разлике међу генерацијама везане за превенцију зачећа? Резултати репрезентативног истраживања спроведеног 2006. године показују да $18,6 \%$ жена на ризику за настанак трудноће користи модерну контрацепцију (кондом, комбиновану хормонску контрацепцију или интраутерини уложак), као и да се највећи број жена и на почетку и на крају репродуктивног периода ослања на традиционалне методе у превенцији зачећа. Наведени налази отварају више питања међу којима је најзначајније - зашто нема помака ка коришћењу модерне и ефикасне контрацепције међу младим паровима? Неки одговори се намећу. Међу њима најважнији су да традиционална контрацепција и намерни прекид трудноће имају чврсту социјалну потврду, да сексуална едукација није никада постала ни природни део одрастања у породици ни саставни део школских програма, да постоји велики психолошки отпор према употреби комбиноване хормонске контрацепције и интраутериног улошка, као и да се ослањањем на coitus interruptus избегава конфликт између сексуалности и технологије, контакт са лекаром, али и сукоб с партнером.

Кључне речи: намерни прекид трудноће, контрацепција, Србија. 